\title{
Anglo-Saxon Architecture
}

\section{T. Wright}

To cite this article: T. Wright (1844) Anglo-Saxon Architecture, Archaeological Journal, 1:1, 24-35, DOI: $10.1080 / 00665983.1844 .10850512$

To link to this article: http://dx.doi.org/10.1080/00665983.1844.10850512

曲 Published online: 10 Jul 2014.

Submit your article to this journal $\widetilde{ }$

III Article views: 7

Q View related articles $₫$ 


\section{ANGLO-SAXON ARCHITECTURE,}

\section{ILLUSTRATED FROM ILLUMINATED MANUSCRIPTS.}

The subject on which it will be my endeavour to throw some additional light in the present paper is one of great obscurity. Old writers on architectural antiquities carelessly jumbled together almost all monuments distinguished by the absence of the pointed arch under the title of Saxon. Some more recent antiquaries have gone into the opposite extreme of asserting that there are now remaining no specimens of Anglo-Saxon buildings. The difficulty attending this question arises from the absolute impossibility of identifying existing structures of an early period with historical dates. This difficulty has been increased by the adoption of several general assertions, which I am inclined to believe altogether incorrect. It has been stated that parish churches were very rare among the Anglo-Saxons, that they were small unsubstantial buildings, and even that they were built of nothing but wood. I think the notion that Anglo-Saxon churches were all built of wood will now hardly find supporters. We know that there were structures of this material; a few wooden churches are mentioned in Domesday Book; Ordericus Vitalis mentions a wooden chapel on the banks of the Severn, near Shrewsbury, which was probably built a very short time before the Norman conquest ${ }^{\mathrm{a}}$; and there was a wooden church at Lytham in Lancashire, which was destroyed, and a stone church built by its Norman lord, as we learn from Reginald of Durham $^{\mathrm{b}}$. This last writer, only two pages after, mentions a church of stone at Slitrig in Teviotdale, although only a chapel dependant on the church of Cavers, and which must have been older than the Conquest, for in the twelfth century it was a roofless ruin ${ }^{c}$. The notion that the Anglo-Saxon churches were few and small, is chiefly founded upon some

a Illic nimirum lignea capella priscis temporibus a Siwardo Edelgari filio, regis Edwardi consanguineo, condita fuerat. Ord. Vit. ed. Le Prevost, vol. ii. p. 4.16.

- Nam prædicti militis avus ecclesiam præfatam quondam asserum viliore com- page constructam, a fundamentis diruerat : pro qua et aliam lapideam in honore sancti confessoris, licet non omnino in eodem loco confecerat.-Reginald. Dunelm. (Surtees' Publication), p. 282.

c Reginald, Dunelm. p. 284. 
general assertions of the Anglo-Norman monkish chroniclers, to which we ought to give very little value; for not only was it the fashion for at least two centuries after the Conquest to speak contemptuously of every thing Saxon, but general assertions of the old monkish chroniclers are seldom correct. It is my belief that a careful perusal of the early chroniclers would afford abundant proof that churches were not only numerous among the Anglo-Saxons, but that they were far from being always mean structures. It is not the object of the present observations to enter into this part of the subject, but I will cite two passages which offer themselves almost spontaneously on accidentally opening two well-known writers. Ordericus Vitalis, speaking of the state of England in 1070, only four years after the Conquest, says, "Fiebant et reparabantur basilice, et in eis sacri oratores obsequium studebant Deo debitum persolvere "." Churches to be repaired at this time must have been Saxon, and I think of stone; if they had been mean structures, and in need of repairs, it is more probable that the Normans would have built new ones. There can be no doubt that the Anglo-Saxons paid much less attention to architecture than the Normans. William of Malmesburye, speaking of the laxity of manners among the Anglo-Saxons in the age preceding the Conquest, says, "Potabatur in commune ab omnibus, in hoc studio noctes perinde ut dies perpetuantibus, parvis et abjectis domibus totos sumptus absumebant, Francis et Normannis absimiles, qui amplis et superbis redificiis modicas expensas agunt." And a few lines after he adds, "Porro Normanni ..... domi ingentia adificia (ut dixi) moderatos sumptus moliri." This passage must not be taken as a proof of the meanness of Anglo-Saxon architecture in general; it is merely a somewhat indefinite statement of a well-known fact, that the Saxon nobles did not establish themselves in vast feudal castles like those of the Anglo-Normans. William of Malmesbury goes on to describe the change among the clergy under the Normans, and observes, "Videas ubique in villis ${ }^{f}$ ecclesias, in vicis et urbibus monasteria, novo

\footnotetext{
A Orderic. Vital., vol. ii. p. 215. Savile.

De Reg. Angl,, lib. iii. p. 102. ed.

The meaning of the word villa at this period is fixed by the following passage of Ordericus Vitalis, vol. ii. p. 223. Gautredus Constantiniensis episcopus ... qui certamini Senlacio fautor acer et consolator
} interfuit, et in aliis conflictibus . . . ma-
gister militum fuit, dono Guillelmi regis
ducenas et octoginta villas (quas a manen-
do manerios vulgo vocamus) obtinuit. It is
said of Lanfranc (A.D. 1070-1089) in
MS. Cotton. Claud. C. vi. fol. 168. vo.
(written in the twelfth century), In maneriis
ad archiepiscopum pertinentibus multas et 
adificandi genere consurgere." The expression, a new style of bulding, is important in two points of view : the way in which it is introduced shews that churches in another style of build-

SUFPOSED ANGLO-3AXON TOWERS.
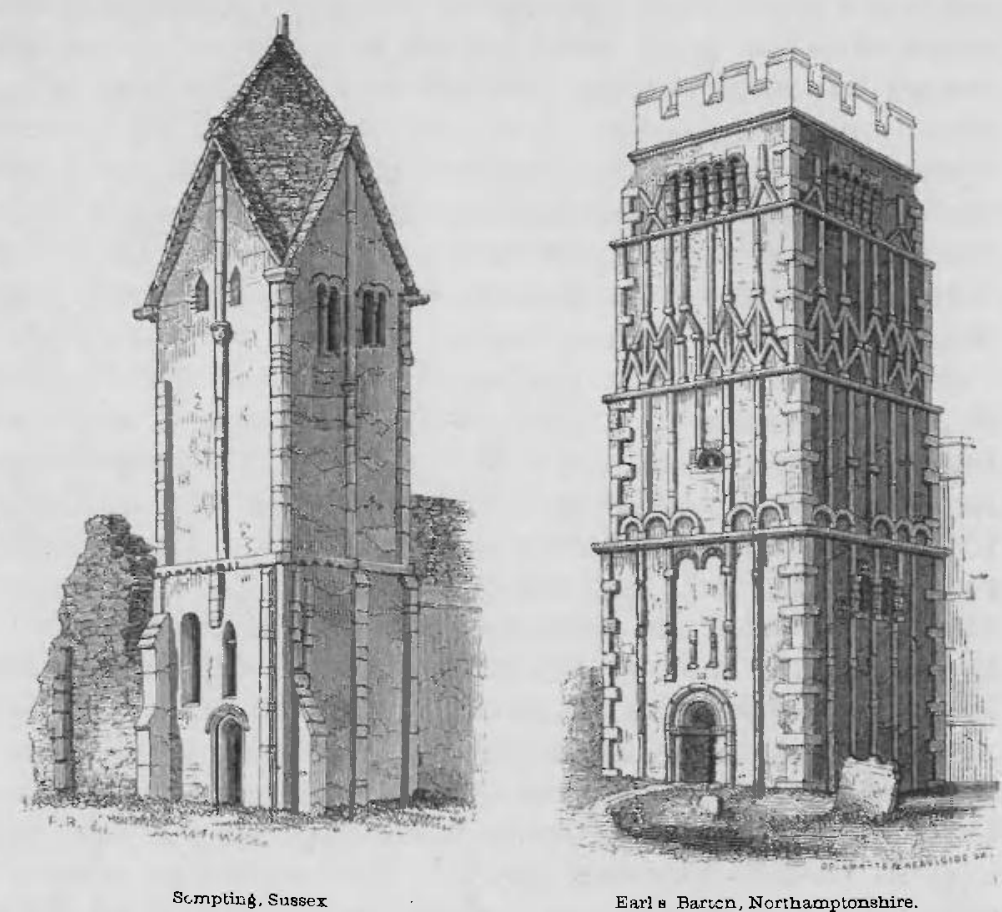

ing were in existence, and that they were numerous, for William of Malmesbury (who is good authority on this point) does not tell us that the number of churches was at first multiplied greatly by the Normans; and, secondly, it proves that there was a marked difference of style between the ecclesiastical buildings of the Anglo-Saxons and those of the Anglo-Normans. Recent antiquaries have accordingly found architectural remains in several parish churches where other parts of the building are Norman, differing so remarkably from the Nor-

honestas ecclesias ædificavit. We might expect to find good specimens of the earliest Norman in some churches in Kent, in the estates which formerly belonged to the Archbishop of Canterbury. It is not probable that the churches built by Lanfranc would need rebuilding before the thirteenth or fourteenth centuries. We may identify these estates by Domesday Book. 
man parts of the same building, and from Norman architecture in general, that they have not hesitated to attribute them to our Anglo-Saxon forefathers. These characteristics are chiefly observed in massy steeple-towers, such as those of Sompting in Sussex, and Earl's Barton in Northamptonshire; and it is probable that the tower was the strongest and most durable part of an Anglo-Saxon parish church, and would therefore be most likely to be preserved amid Anglo-Norman repairs.

There is a source of information on the subject of AngloSaxon Architecture which has hitherto been neglected, and which has always appeared to me to be of great importance. I mean, illuminated manuscripts ; and it is the object of the present essay to shew how remarkably they support the belief that the remains just alluded to are Anglo-Saxon. Illuminated manuscripts are, for the middle ages, what the frescoes of Pompeii and Herculaneum, and the paintings of the Egyptian pyramids, are for more ancient times; they throw more light than any other class of monuments on the costume and on the domestic manners of our forefathers. These manuscripts, which extend through the whole period of the middle ages, are full of architectural sketches. At the time when they are most abundant, i. e. subsequent to the twelfth century, these sketches are of less value, because the monuments themselves are numerous, and their dates more easily established; still they afford much information on domestic and military architecture. But at an earlier period, they furnish data which we have no other means of obtaining. It may be observed that the medieval artists, whatever subject they treated, represented faithfully and invariably the manners and fashions of the day; and that from the language and character of the writing we are enabled to fix their date with great nicety. The manuscript to which attention is now called, is a fine copy of Alfric's Anglo-Saxon translation of the Pentateuch, now preserved in the British Museum, MS. Cotton. Claudius B. IV. It was written in the closing year of the tenth century, or at the beginning of the eleventh, i. e: about the year 1000 or very shortly after, and is filled with pictures, containing a great mass of architectural detail. The proportions are often drawn incorrectly, (the universal fault of the Anglo-Saxon artists,) but the architectural character is perfectly well defined. 
The cut, fig. 1, presents some of the characteristics of most frequent occurrence in this manuscript. It represents an arcade, with a door under one of the arches. Columns and capitals of this simple form aremost common, and the arches, when round, are all re-productions of this type. It has not been thought necessary to give in our cuts the figures of personages with which all

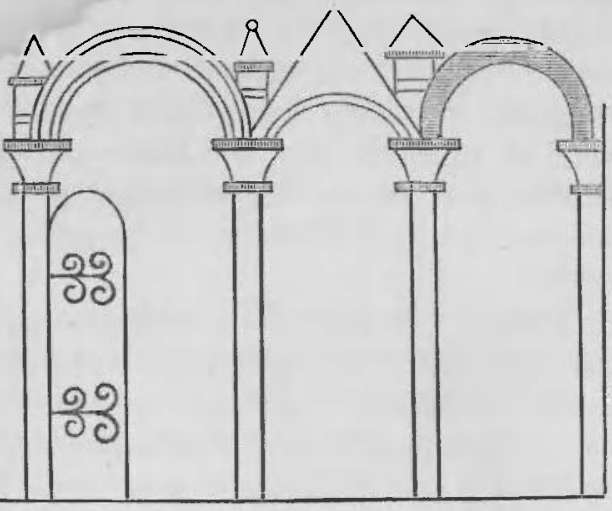

(Fig. 1 ) arcade, Ms Jotton, Claud. B. iv. fol. $36 v^{\circ}$ these drawings are accompanied in the originals. Under the arches and doorways we not unfrequently observe kings and ministers seated, and distributing justice, in the manner represented in our cut, fig. 2, where a messenger is entering, the bearer of intelligence, through the triangular-

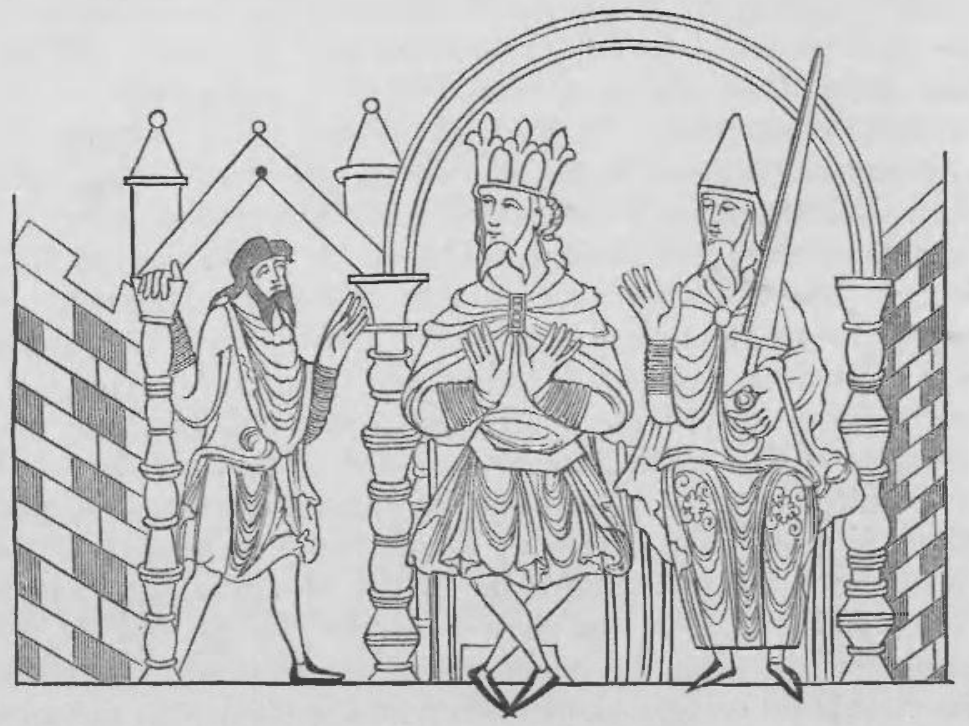

(Fig 2) Arrhes.from the same MS..fol 37. vo

headed doorway on the left. The manner in which the messenger places his hand at the top of one of the columns must be accounted for by the unskilfulness of the artist. The 
compartments of the walls which are lightly shaded in the engraving, are in the original painted yellow. Polychromy is observable in all the architectural subjects throughout the manuscript ; the arches, and even the mouldings, and different parts of the columns, are painted of various hues. The colours most frequent are yellow and blue. It may perhaps be doubted how far we may depend on the strict truth of the colours employed by the early artists, for in some instances they seem to be extremely fanciful. I have met with pictures in which men's hair was painted of a bright blue; but it is not impossible that at some period it may have been the custom to stain the hair of that colour. However, be the colours true or not, these drawings appear to establish the fact, that the Anglo-Saxon buildings were painted in this variegated manner.

The figure given above contains other characteristics of importance, which frequently recur in the manuscript, especially the baluster columns. Among other instances of similar pillars, one of the most remarkable is that given in the margin (fig. 3), which occurs at folio 74, $\mathrm{r}^{\circ}$. Here again (as in all the cuts $I$ have taken from this manuscript) the part shaded in the engraving is coloured in the original. These are precisely the kind of columns which are still found in some remains of buildings supposed to be of the Saxon era. They occur in the oldest parts of the church of St. Alban's, where we find also the same triangular-headed arches which occur so frequently in our manuscript. A series of the baluster columns at St. Alban's are engraved from drawings by Carter, in the plates published by the Society of Antiquaries (Muniment. Antiq., vol. i. pt. 15), from which the example given in the present page, fig.

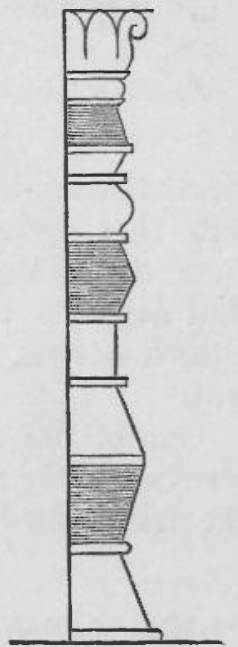

Fis. 3 . 4 , is copied. These columns are characterized by the same double and treble band-mouldings, in the different parts of the column, as appear in our cut, fig. 2. I see no reason for disbelieving that the baluster columns and triangular-work are parts of a church of St. Alban's built early in the eleventh century 
with the Roman materials which had been collected from the laborious and continued excavations of many years, by Abbots Ealdred and Eadmar, among the ruins of the ancient city of Verulamium $^{\mathrm{g}}$. Most of the church-steeples supposed to be $\cdot$ Anglo-Saxon, contain belfry-windows with columns of this description. For the sake of comparison, I give two examples (figs. 5 and 6) from the towers of Earl's Barton church in

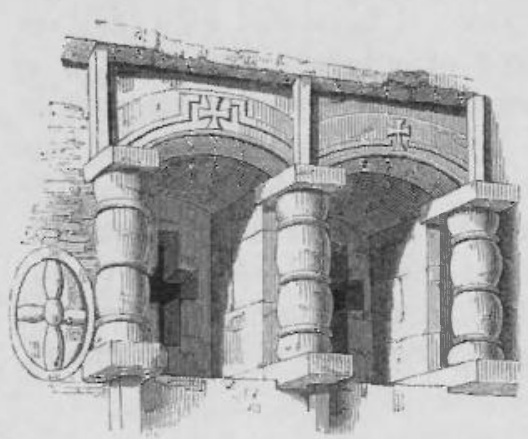

(Fig 5. Eirl's Barton, Northamptonsbire.

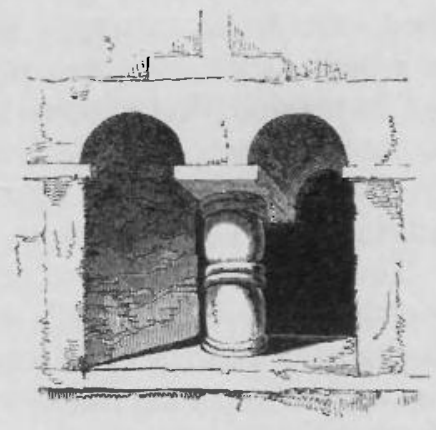

Fis 6. St. Benet s, Cambridge.

Northamptonshire, and St. Benet's in Cambridge. They have only that difference in design from the specimens selected from the Cottonian manuscript, which we might expect to find between the columns of a small window in a parish church-steeple, and the larger ornamental columns of a doorway.

One of the most striking, and constantly recurring characteristics of the architecture of our Anglo-Saxon manuscript, is the triangular-headed doorway. We have already seen an

g It has been observed, I think by Rickman, that the great quantity of tiles observed in the old parts of St. Alban's church renders it probable that they were not taken from older Roman buildings, but made for the occasion. I think, however, that this assumption is by no means of sufficient strength to outweigh the distinct testimony of the old chronicler relating to the excavations carried on during the lives of the two succes ive abbots, both of whom, he says, collect ed in this manner the tiles and stones for the building: of Abbot Ealdred, he states, Tegulas vero integras et lapides quos invenit, aptas ad ædificia seponens, ad fabricam ecclesiæ reservavit (M. Paris. Hist. Abb. p. 40); and of his successor Eadmar, Et cum abbas memoratus profundiora terræ ubi civitatis Verolamii apparuerunt vestigia diligentur perscrutaretur, et antiquos tabulatus lapideos cum tegulis et columnis inveniret, quæ ecclesiæ fabricandæ fuerunt necessaria, sibi reservaret, \&c. (p. 41). It may be observed that the Anglo-Saxon tegel, our tile, signified tiles and bricks of whatever description (if made of baked earth): hrof-tegel was the term used for the tiles used to cover roofs of buildings. 
instance in fig. 2. The cut, fig. 7, represents an arrangement which is frequently repeated in the manuscript : the difference in the shades represents the two different colours with which it is painted. In fig. 1, we have seen a low round arch within a triangle. In fig. 8, we have a double arch, joining in a sort of pendant, similarly placed within a triangle. Fig. 9. represents a triangular tympanum. The first of these two last-mentioned figures appears, by the capitals, to be intended as part of a more richly decorated building than that to which the other belonged.

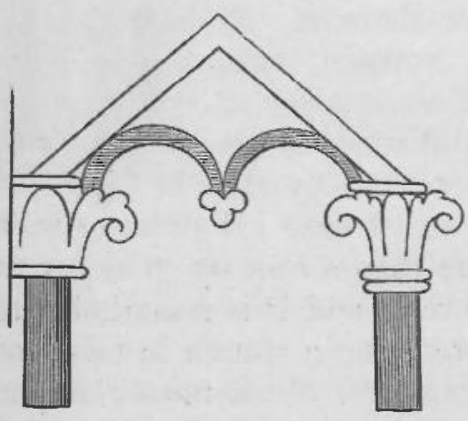

(Fiés 8.) MS. Cotton, foi. 64. $\nabla^{\circ}$.

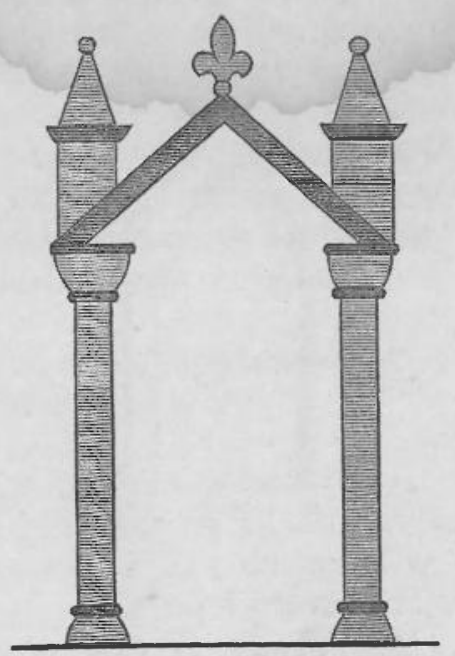

(Fis 7) MS, Cotton, fol, $57, v^{\circ}$

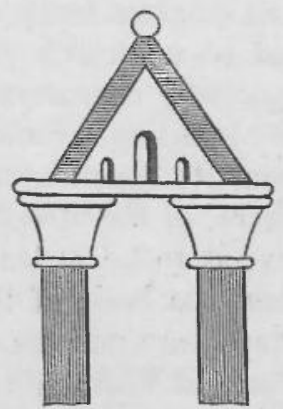

(Fis, 9.) fol. $65 . y^{\circ}$.

I have already stated that triangular arches are found in the oldest parts of the abbey church of St. Alban's. They occur as windows in most of the steeple-towers of the character supposed to be Saxon, and are also found in some instances as doorways. We have a doorway of this description in Barnack church, Northamptonshire, and another in Brigstock church, in the same county. Windows of this description are still more common. Of the following cuts, fig. 10. represents a doorway in the church of Barnack; fig. 11. a very curious belfry-window in the church of Deerhurst, in Gloucestershire; 
and fig. 12. a window from the tower of Sompting church in Sussex.

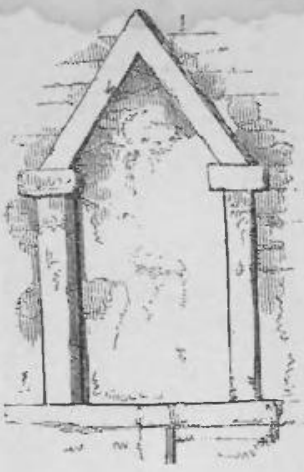

(Fig. 10,) Barnack.

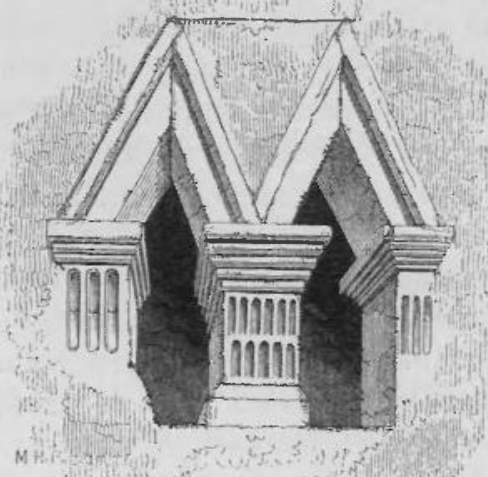

(Fie. 11.) Deerhursc, Gloucestershire.

The church of Sompting presents a very interesting specimen of what appears to be an Anglo-Saxon steeple, and one which seems to have preserved its original form, even to the roof. It is joined to a church of late Norman style, but apparently containing also some relics of an earlier building. From the difference of the stone, and its much greater corrosion by the atmosphere, in the steeple, we are at once led

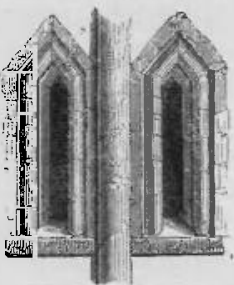
to believe it to be at least more than a century (perhaps two) older than the body of the church; and it is remarkable that Domesday bears witness of there being a church in this parish in the time of William the Conqueror, which must then have been old, to need rebuilding so soon as the middle of the twelfth century, which appears to be about the date of the body of the present church. There can be little doubt that the present steeple belonged to the older church, which was standing here at the time of the Conquest. It is very much to be desired that a list should be made of all the parish churches mentioned in the Domesday Survey, and that the churches now existing in the same places should be carefully examined. Among the illuminations of the manuscript of Cædmon, pl. 59, as published in the Archxologia, vol. xxiv., there is a rude but curious figure of an Anglo-Saxon church, the steeple of which bears considerable resemblance in form to those of which we are speaking. The date of Deerhurst tower 
appears also to be justly fixed to a period antecedent to the Norman conquest. The original inscribed stone is still preserved among the Arundelian marbles at Oxford, which states that the church of Deerhurst was consecrated on the 11th of April, in the fourteenth year of the reign of Edward the Confessor, which would be A.D. 1056 , or 1057 , according as the regnal year may have been counted from Edward's accession or from his coronation. A new steeple could hardly have been wanted during the Anglo-Norman period; and as the one now standing cannot have been built at a later period, we seem justified in concluding that it was the original Saxon tower.

Fig. 13. represents another of these triangular-arched doorways from the Cottonian manuscript. It is accompanied with what is intended to represent a dome. Domes occur frequently in the manuscript, and form a connecting link between Anglo-Saxon and Byzantine Architecture. The dome represented in our cut appears to be covered in a very singular manner with parallel

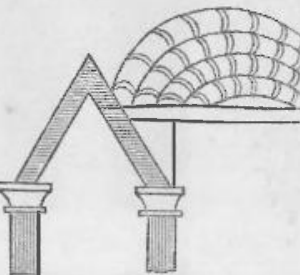
semicircles, apparently of tiles; the form (Fis. 13.) Ms. Cotton fol. $38 . \mathrm{v}^{\circ}$ which occurs more generally in the manuscript has a knob or ball at the summit, from which, as a centre, the rows of tiles radiate. It may be observed also, that in these drawings the roofs are generally covered with tiles which, in form and arrangement, bear a close resemblance to the scales of a fish.

The capitals of columns in this manuscript are also deserving of attention. Several examples have been given in the cuts which illustrate the preceding pages : the following additional varieties are selected from different parts of the volume.

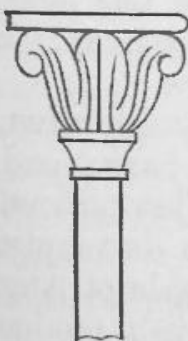

Fis. 14.
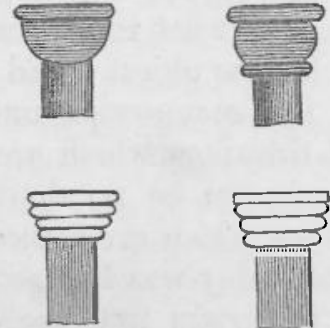

Figs. 15 to 18

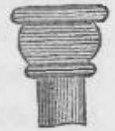

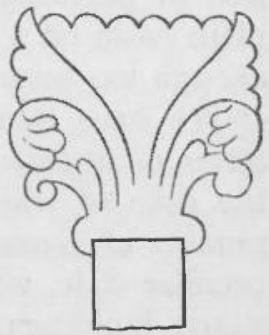

Fig. 19.

The most simple and common form is that which has been represented in figs. $1,2,9$, and 13 . The capitals more richly 
ornamented are generally formed of leaves, as in figs. 3, 8, 14, and 19. The foliated capitals, of course imitated from the older Roman, are characteristic of the Byzantine and Romanesque styles. I think they are not found in early Norman, but begin to be introduced towards the period of transition. Foliated capitals of a peculiar and elegant description (fig. 20.)
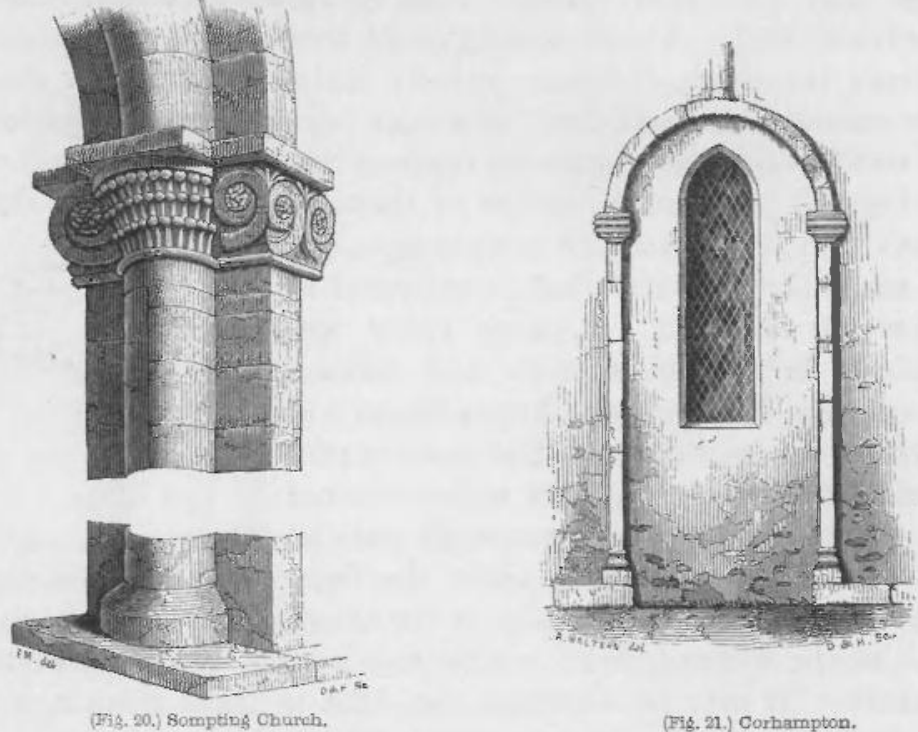

occur in the doorway of the tower of Sompting church. An arch in Corhampton church, in Hampshire, rests upon imposts bearing a very close resemblance to the rudely drawn capitals of the manuscript represented in our figs. 17, 18. The manuscript presents some other architectural characteristics, and in particular several figures of fonts, all of one form, a plain basin on a shaft, somewhat resembling an egg-cup. But enough has been said for the object I had in view.

We have then, in the manuscript under consideration, a series of architectural drawings which are pure Saxon, and of the date of which there can be no doubt. They present a number of characteristics which are sufficient to distinguish a peculiar style, which probably was the general style of AngloSaxon buildings. It is certain that the old artists produced nothing on parchment which was not modelled on what really existed before their eyes. I would add, that although illuminated manuscripts become more numerous after the Conquest, 
I never met with one of a later date exhibiting any of the peculiar characters mentioned above. We find a similar style on parts of existing buildings which are evidently of a very early date, and which therefore, as it appears to me, we are justified in attributing to the same age as the manuscript, in the same way that we should ascribe an unknown effigy to the age in which its costume is found to prevail in similar illuminations. It remains for further examination to shew how far we ought to refer every example of this style to the same age. The dates of early buildings appear to have been often fixed too arbitrarily. I would merely cite, as an instance, the church of Waltham abbey. This is considered as early Norman, and ascribed to the date of about 1120, because Henry I. and his two wives are recorded as special benefactors to the monastery. In the two most authentic accounts of the early history of Waltham abbey, both written apparently late in the reign of Henry II., the Vita Haroldi and the tract De Inventione Sancte Crucis Walthamensis (the latter of which brings the history up to the time at which it was written), we have a particular and 'curious account of Harold's church, which was very spacious and massive, and which agrees perfectly with what now remains; and these same documents give us every reason to believe that no remarkable alterations had been made in the building up to the time at which these histories were written, that is, up to the period of transition. This is very easily accounted for, because the acknowledged character of Harold's building would preserve it from dilapidation, and the jealousy with which it was looked upon by the Normans (as we are informed in the documents) caused it to be treated with neglect. It may be observed also, that Harold's church was most probably built by architects brought over from Normandy, and would therefore have a decidedly Norman character. I will merely add that a copy of Prudentius in the British Museum, written apparently about the middle of the eleventh century (or very soon after), MS. Cotton. Titus D. XVI., contains one or two rows of columns of which the shafts are ornamented in precisely the same style as those which still remain in Waltham abbey.

T. WRIGHT. 